\title{
PEMBUATAN MODUL PEMBELAJARAN AUTOCAD PADA MATA PELAJARAN APLIKASI PERANGKAT LUNAK DAN PERANCANGAN INTERIOR GEDUNG DI SMK NEGERI 3 YOGYAKARTA
}

\author{
Ahmad Aldo \\ Pendidikan Teknik Sipil dan Perencanaan, FT, UNY \\ Email: ahmad.aldo2016@student.uny.ac.id
}

\begin{abstract}
ABSTRAK
Tujuan dari kajian ini adalah untuk mengetahui: (1) tahapan pembuatan modul pembelajaran AutoCAD di SMK Negeri 3 Yogyakarta dan (2) kelayakan modul pembelajaran AutoCAD berdasarkan pendapat ahli materi, ahli media, dan guru. Kajian ini merupakan jenis penelitian pengembangan dengan model 4-D yang terdiri dari empat langkah penelitian. Pengumpulan data dilakukan dengan angket yang didukung kegiatan observasi dan wawancara. Hasil kajian menunjukkan bahwa (1) produk modul pembelajaran dapat disusun dengan proses yang menghasilkan materi mencakup: a) definisi perangkat lunak AutoCAD; b) tampilan dan tahapan pengelolaan file AutoCAD; c) prinsip gambar dua dimensi; d) persiapan menggambar dengan AutoCAD; e) pembuatan gambar detail; f) pembuatan gambar rancangan; g) pembuatan etiket gambar dan pencetakan gambar. Sementara itu, (2) hasil validasi modul berdasarkan ahli materi mendapatkan skor 3,55 dengan kategori sangat layak. Validasi berdasarkan ahli media mendapatkan skor 3 dengan kategori layak. Sedangkan validasi guru mendapatkan skor 2,95 dengan kategori layak.
\end{abstract}

Kata kunci: AutoCAD, media pembelajaran, modul, penilaian, validasi

\section{ABSTRACT}

The objectives of this study are knowing: (1)the stages of making AutoCAD learning module in Vocational High School 3 Yogyakarta and (2) the feasibleness of AutoCAD based on opinions from subject expert, media expert, and teacher. This research is a type of development research with a 4-D model which consists of four research steps. Data collection was carried out with a questionnaire that is supported by observation and interview. The results of the study show that (1) the learning module product can be arranged with processess that produce subjects including: a) definition of principle of two-dimensional drawing; $b$ ) display and stages of managing AutoCAD files; c) the principle of two-dimensional drawing; d) preparation for drawing with AutoCAD; e) making detailed drawings; f) Making design drawings; g) making the format drawings and printing drawings. Meanwhile, (2) the results of the module validation based on the subjects expert get a score of 3,55 with very feasible category. Validatoon based on media expert get a score of 3 with feasible category. While the teacher validation get a score of 2,95 in the feasivle category.

Keywords: Assesssment, AutoCAD, learning media, module, validation

\section{PENDAHULUAN}

Sekolah Menengah Kejuruan (SMK) merupakan salah satu bentuk satuan pendidikan formal yang menyelenggarakan pendidikan kejuruan pada jenjang pendidikan menengah sebagai lanjutan dari SMP, MTs, atau bentuk lain yang sederajat (Undang-Undang Nomor 20 Tahun 2003 tentang Sistem Pendidikan Nasional). Peserta didik lulusan SMK diharapkan menjadi Sumber Daya Manusia (SDM) yang diterima dalam dunia pekerjaan. Oleh karena itu, peserta didik SMK seharusnya memiliki kompetensi pengetahuan, keterampilan, dan sikap yang baik, sehingga dapat menjadi lulusan yang sesuai dengan kebutuhan Dunia Usaha dan Dunia Industri (DUDI).

Akan tetapi, Berdasarkan data Badan Pusat Statistik (BPS) (2019), sebenarnya dari 136,18 juta orang yang tergabung dalam angkatan kerja, terdapat 6,82 juta orang yang 
menganggur. Fakta yang mengenaskannya adalah bahwa lulusan SMK menjadi penyumbang pengangguran terbanyak dengan jumlah mencapai 588 ribu orang (8,63\%). Fakta ini mengejutkan. Jenjang pendidikan kejuruan yang seharusnya tempat pembentukan SDM berkualitas bahkan menjadi beban dalam menghasilkan sumber pengangguran terbesar.

Dari komponen kurikulum sendiri banyak aspek yang mempengaruhi kualitas pembelajaran dan berdampak pada kualitas lulusan. Dalam Undang-Undang Nomor 20 Tahun 2003 tentang Sistem Pendidikan Nasional telah dijelaskan bahwa kurikulum merupakan seperangkat rencana dan pengaturan mengenai tujuan, isi, dan bahan pengajaran serta cara yang digunakan sebagai pedoman penyelenggaraan kegiatan pembelajaran untuk mencapai tujuan pendidikan nasional. Artinya hanya dari sisi kurikulum terbagi lagi mengenai tujuan, isi, bahan pembelajaran, serta metode penyelenggaraan pendidikan yang tepat untuk diterapkan di dalam kelas. Oleh karena itu, untuk mewujudkan suatu penyelenggaraan kurikulum yang tepat perlu dilakukan identifikasi sampai unit terkecil seperti pembelajaran di dalam kelas.

Berdasarkan fakta di atas dilakukan pengamatan di SMK Negeri 3 Yogyakarta, tepatnya pada suatu kompetensi keahlian Desain Pemodelan dan Informasi Bangunan (DPIB). Pengamatan dilakukan terhadap penyelenggaraan beberapa mata pelajaran di dalam kelas. Setelah dilakukan pengamatan diketahui bahwa sumber belajar mata pelajaran Aplikasi Perangkat Lunak dan Perancangan Interior Gedung (APLPIG) masih berpatokan pada sumber belajar lama yang telah digunakan sejak tahun 2004. Selain materi tersebut, sebagian materi lainnya disampaikan bedasarkan sumber belajar dari internet yang belum terbukti valid.

Berdasarkan permasalahan dilakukan upaya pembuatan modul pembelajaran yang berisi tentang pembahasan penggunaan perangkat lunak AutoCAD. Pemilihan pembuatan modul tidak terlepas dari karakteristiknya yang dapat diterapkan sebagai sumber belajar mandiri yang sejalan dengan prinsip Kurikulum 2013 Revisi (K13 Revisi). Isi materi modul disesuaikan usia dan tingkat pengetahuan siswa agar pembelajaran dapat berlangsung secara mandiri dengan sedikit bimbingan dari guru (Andi, 2012). Dengan makna yang serupa, Sukiman (2011) mengemukakan bahwa modul adalah bagian kesatuan belajar yang terencana dan dirancang untuk membantu siswa secara individual dalam mencapai tujuan belajarnya.

Modul ini membahas mengenai teoriteori dan prinsip penggambaran bangunan yang perlu diterapkan sesuai dengan perkembangan teknologi saat ini. Selain itu, dalam modul ini dilengkapi dengan rangkuman dan contoh soal untuk dipahami dan dikerjakan peserta didik sebagai latihan pengayaan. Adanya modul dapat berdampak pada peningkatan pengetahuan penggunaan perangkat lunak AutoCAD yang sesuai dengan kebutuhan DUDI. Selain itu, ketersediaan modul dapat dimanfaatkan sebagai sumber belajar mandiri agar tidak selalu bergantung dengan penjelasan/ pemeriksaan dari guru.

Dari penjelasan di atas dapat dilaksanakan kajian pembuatan modul pembelajaran dengan tujuan 1) Mengetahui tahapan pembuatan modul pembelajaran AutoCAD untuk menjadi suatu media pembelajaran dalam mata pelajaran APLPIG di SMK Negei 3 Yogyakarta; 2) Mengetahui tingkat kelayakan dari suatu produk modul 
Pembuatan Modul Pembelajaran... (Aldo/ hal. 37-51)

pembelajaran berdasarkan pendapat dari ahli materi, ahli media, dan guru.

\section{METODE}

Kajian pembuatan modul dilaksanakan dengan jenis penelitian pengembangan/ Research and Development (R\&D). R\&D merupakan metode penelitian yang digunakan untuk menghasilkan produk tertentu dan menguji keefektifan produk tersebut (Sugiyono, 2012). Sementara itu, menurut Borg \& Gall (2002), penelitian dan pengembangan untuk bidang pendidikan adalah proses yang digunakan untuk mengembangkan dan sekaligus memvalidasi produk pendidikan. Oleh karena itu, penelitian $\mathrm{R} \& \mathrm{D}$ dapat diterapkan dalam penelitian pendidikan yang mengembangkan produk dengan cara mengujinya agar menghasilkan perubahan positif pada bidang pendidikan. Pelaksanaan penelitian R\&D dapat dilakukan melalui beberapa model. Namun, hasil dari masing-masing model penelitian R\&D tetap berujung pada produk yang telah divalidasi dan dinyatakan layak digunakan.

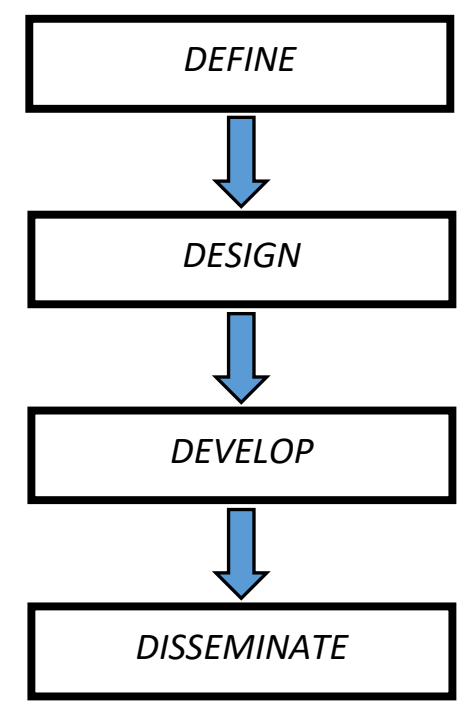

Gambar 1. Prosedur Penelitian Pengembangan

Model 4-D
Dalam penelitian ini dipilih model 4D. Menurut Thiagarajan (1974), model penelitian dan pengembangan 4-D terdiri atas empat tahap utama, yaitu: 1) Define atau pendefinisian; 2) Design atau perancangan; 3) Develop atau pengembangan; dan 4) Disseminate atau penyebaran. Adapun dari masing-masing tahapan tersebut dapat disusun diagram alir model 4-D seperti pada Gambar 1.

Prosedur penelitian pengembangan model 4-D yang terdiri dari empat tahap dapat dikelompokkan kembali menjadi beberapa tahap penelitian. Pada tahap Define (Pendefinisian) dilaksanakan berbagai kegiatan dengan tujuan mengumpulkan informasi yang berkaitan dengan produk modul pembelajaran. Kegiatan dilakukan dengan menentukan isi materi yang perlu dikembangkan agar dapat membentuk suatu modul pembelajaran. Adapun tahap pendefinisian dibedakan kembali menjadi lima tahapan yang mencakup 1) Front-end analysis (Analisis awal); 2) Learner analysis (Analisis siswa); 3) Task analysis (Analisis tugas); 4) Concept analysis (Analisis konsep); 5) Specyfying instructional objectives (Spesifikasi objek instruksional).

Untuk tahap Design (Perencanaan), berbagai kegiatan kajian yang dilakukan dikelompokkan menjadi 1) Construction crietion-referenced test (Susunan kriteria); 2) Media selection (Pemilihan media); 3) Format selection (Pemilihan format); 4) Initial design (Rancangan awal). Sedangkan untuk tahap Develop (Pengembangan) dilakukan dua kegiatan kajian yang menjadi kegiatan inti dalam pelaksanaan kajian. Kegiatan ini terdiri dari 1) Expert appraisal dan 2) Developmental testing. Expert appraisal menjadi tahapan validasi produk modul yang dilaksanakan oleh ahli materi, 
ahli media, dan guru. Sementara developmental testing merupakan tahapan penilaian yang dilakukan oleh siswa terkait dengan kualitas modul pembelajaran.

Sementara itu, tahap Disseminate (Penyebaran) terdiri dari kegiatan 1) Validation testing; 2) Packaging; dan 3) Diffusion and adaption. Pada tahap validation testing, produk modul yang sudah direvisi diimplementasikan pada siswa sebagai media pembelajaran. Setelah modul diimplemnetasikan, tim pengembang perlu melihat hasil pencapaian siswa. Apabila tujuan belum tercapai, dapat dilakukan pengembangan kembali. Kegiatan terakhir yaitu melakukan packaging, diffusion and adaption. Pada tahap ini dilakukan penyebaran media pembelajaran dalam bentuk softfile dan hardfile kepada guru mata pelajaran APLPIG.

Kajian ini dilaksanakan di ruangan Laboratorium CAD Kompetensi Keahlian DPIB SMK Negeri 3 Yogyakarta. Fokus kajian untuk pengembangan kisi-kisi angket dan persiapan tanggal pengambilan data. Selain itu, diprioritaskan juga untuk pengambilan data modul ke ahli materi, ahli media, guru, dan siswa.

Adapun untuk subjek dalam kajian ini dibedakan berdasarkan ahli materi, ahli media, dan pengguna. Ahli materi diwakili oleh dosen sebagai akademisi di Jurusan Pendidikan Teknik Sipil dan Perencanaan (JPTSP) Universitas Negeri Yogyakarta (UNY) yang telah berpengalaman mengajar dan meneiliti bidang serupa. Ahli media juga diwakili oleh akademisi JPTSP UNY dari latar belakang ilmu kependidikan. Sementara itu, subjek pengguna terdiri atas pendidik (guru) dan peserta didik (siswa).
Pengumpulan data dilakukan dengan beberapa teknik yang dikelompokkan berdasarkan data primer dan data sekunder. Data primer merupakan data yang dapat dikumpulkan secara langsung. Sementara data sekunder dikumpulkan melalui studi pustaka.

Teknik pengumpulan data primer dilakukan melalui angket dengan didukung oleh observasi dan wawancara yang tidak terstuktur. Observasi dilakukan untuk mengamati suatu kegiatan pembelajaran dari pelajaran APLPIG dan mengidentifikasi permasalahan yang dihadapi. Wawancara dilakukan untuk mengumpulkan data yang berdasarkan pendapat peserta didik dan pendidik. Angket digunakan sebagai alat pengumpul dari dari model pengembangan R\&D. Data angket diambil berdasarkan aspek materi, media, dan pengguna dari modul yang telah dibuat. Oleh karena itu, Data angket diisi oleh ahli materi, ahli media, guru, dan siswa.

Pada kajian ini, untuk pemilihan instrumen pengumpulan data dilakukan menggunakan angket. Pemilihan angket didasari atas faktor kemudahannya dalam diterapkan sebagai alat pengumpulan yang bertujuan mengetahui kelayakan modul pembelajaran yang telah tersusun. Terlebih lagi, angket telah menjadi instrumen umum yang sering digunakan sebagai alat pengumpulan kajian pengembangan.

Angket mengenai materi dalam modul didasari Direktorat Pembinaan SMK Depdiknas Tahun 2008 tentang Penulisan Modul yang terdiri dari lima karakteristik sebuah modul, meliputi: 1) self instruction; 2) self contained; 3) stand alone; dan 4) adaptive; serta 5) user friendly. 


\section{Pembuatan Modul Pembelajaran... (Aldo/ hal. 37-51)}

Tabel 1. Kisi-kisi Angket untuk Ahli Materi

\begin{tabular}{|c|c|c|}
\hline No. & Aspek & Indikator \\
\hline 1. & $\begin{array}{l}\text { Self instruction } \\
\text { (Pembelajaran } \\
\text { materi mandiri) }\end{array}$ & $\begin{array}{l}\text { Modul dapat menjadikan seorang pengguna dapat melakukan } \\
\text { kegiatan belajar sendiri dan tidak bergantung pada pihak lain }\end{array}$ \\
\hline 2. & $\begin{array}{l}\text { Self contained } \\
\text { (Cakupan materi) }\end{array}$ & $\begin{array}{l}\text { Modul membahas semua materi pelajaran pada mata pelajaran } \\
\text { Aplikasi Perangkat Lunak dan Perancangan Interior Gedung } \\
\text { (APLPIG) untuk kelas XI semester gasal secara utuh }\end{array}$ \\
\hline 3. & $\begin{array}{l}\text { Stand alone } \\
\text { (Kecukupan materi) }\end{array}$ & $\begin{array}{l}\text { Modul dikembangkan tidak tergantung pada media lain atau } \\
\text { tidak harus digunakan bersama-sama dengan media } \\
\text { pembelajaran lain }\end{array}$ \\
\hline 4. & Adaptive (adaptif) & $\begin{array}{l}\text { Isi modul sesuai dengan perkembangan ilmu pengetahuan dan } \\
\text { teknologi serta fleksibel digunakan }\end{array}$ \\
\hline 5. & $\begin{array}{l}\text { User friendly } \\
\text { (kemudahan } \\
\text { penggunaan) }\end{array}$ & Isi modul mudah untuk digunakan dan dipelajari pemakainya \\
\hline
\end{tabular}

Tabel 2. Kisi-kisi Angket untuk Ahli Media

\begin{tabular}{cll}
\hline No. & \multicolumn{1}{c}{ Aspek } & \multicolumn{1}{c}{ Indikator } \\
\hline 1. & Ukuran Modul & $\begin{array}{l}\text { Modul menggunakan ukuran kertas dan isi materi yang sesuai } \\
\text { standar }\end{array}$ \\
2. & Desain Sampul & $\begin{array}{l}\text { Sampul telah menerapkan tata letak, tipografi, dan ilustrasi yang } \\
\text { sederhana dan proporsional }\end{array}$ \\
3. & Dodul & $\begin{array}{l}\text { Isi modul menerapkan tata letak, tipografi, dan ilustrasi yang } \\
\text { sederhana dan proporsional }\end{array}$ \\
\hline
\end{tabular}

Sementara itu, angket terkait validasi media modul mengacu pada ketentuan Badan Standar Nasional Pendidikan (BNSP) (2014) tentang Instrumen Modul Teks Pelajaran. Validasi mencakup aspek 1) Ukuran modul; 2) Desain sampul modul; dan 3) Desain isi modul. Adapun kisi-kisi angket untuk ahli media dapat dilihat pada Tabel 2 di atas.

Sementara itu, dalam penjelasan di atas diketahui bahwa pengguna dibedakan menjadi pendidik (guru) dan peserta didik (siswa). Pendidik diwakili oleh salah satu guru mata pelajaran APLPIG di SMK Negeri 3 Yogyakarta. Sebagai pengguna langsung, guru mewakili status sebagai responden ahli materi dan ahli media. Di sisi lain, siswa sebagai pihak yang belajar dengan modul juga diminta memberikan tanggapan terkait kualitas materi dan media dalam modul. Namun demikian, pengisian angket bagi peserta didik perlu diberikan bimbingan agar mendapatkan hasil yang valid.

Proses validasi dalam kajian ini dilakukan untuk mengetahui kelayakan angket yang telah disusun. Adapun angket yang disusun menjadi alat ukur untuk menentukan kelayakan modul pembelajaran. Kegiatan validasi dilakukan dengan menunjukkan teknik pengumpulan data dan instrumen pengumpulan data yang telah tersusun kepada dua orang akademisi berstatus dosen di JPTSP UNY. Hasil validasi yang telah dilakukan menjadi dasar penetapan kelayakan angket. Jika angket belum layak akan dilakukan revisi dan validasi ulang sampai angket yang disusun layak sebagai instrumen kajian.

Pemilihan teknik analisis data didasari atas pemilihan instrumen kajian. Pada dasarnya angket yang diberikan kepada subjek kajian akan menghasilkan suatu data kuantitatif berupa angka. Oleh karena itu, diperlukan teknik analisis yang dapat 
memudahkan pembahasan dari data yang diperoleh. Atas latar belakang tersebut, dalam kajian ini dipilih teknik analisis deskriptif kuantitatif. Artinya data yang sudah diperoleh dianalisis dan kemudian disederhanakan.

Sebelum tahap pengambilan data, instrumen penelitian dikategorikan menjadi beberapa kajian jawaban dan skor dari yang terendah ke tertinggi. Hal ini dilakukan untuk mendapatkan data yang akurat. Metode yang digunakan berdasarkan pada skala Likert. Dalam Anwar (2007) telah dijelaskan bahwa skala Likert memiliki lima variasi jawaban berupa sangat setuju, setuju, netral, tidak setuju, dan sangat tidak setuju. Namun demikian, dalam kajian ini skala netral direduksi agar hasil pengujian yang dilakukan tidak menghasilkan jawaban yang netral. Adapun untuk keterangan yang lebih jelas dapat dilihat pada Tabel 3.

Tabel 3. Skala Likert dalam Angket

\begin{tabular}{llc}
\hline No. & \multicolumn{1}{c}{ Kategori } & Skor \\
\hline 1. & Sangat setuju & 4 \\
2. & Setuju & 3 \\
3. & Tidak setuju & 2 \\
4. & Sangat tidak setuju & 1 \\
\hline
\end{tabular}

Setelah dilakukan pengambilan data, dilakukan konversi data kuantitatif menjadi kualitatif berdasarkan empat kategori jawaban seperti pada Tabel 4 (Arikunto, 2006).

Tabel 4. Kecenderungan Kelayakan Angket Secara Kualitatif

\begin{tabular}{lll}
\hline No. & \multicolumn{1}{c}{ Rentang Skor } & \multicolumn{1}{c}{ Kategori } \\
\hline 1. & $\mathrm{Mi}+1,5 \mathrm{Sbi}<\mathrm{x}$ & Sangat layak \\
2. & $\mathrm{Mi}<\mathrm{x} \leq \mathrm{Mi}+1,5 \mathrm{Sbi}$ & Layak \\
3. & $\mathrm{Mi}-1,5 \mathrm{Sbi}<\mathrm{x} \leq \mathrm{Mi}$ & Cukup layak \\
4. & $\mathrm{x} \leq \mathrm{Mi}-1,5 \mathrm{Sbi}$ & Kurang \\
\hline
\end{tabular}

Keterangan:

$\mathrm{Mi}=1 / 2($ skor tertinggi + skor terendah $) \ldots . . .(1)$

Sbi $=(1 / 2)(1 / 3)($ skor mak - skor min $)$
Setelah didapatkan kategori jawaban pada setiap komponen penilaian, proses analisis data dilanjutkan dengan menentukan persentase jumlah skor menurut Sugiyono (2012):

Kelayakan (\%) : $\frac{\text { skor kenyataan }}{\text { skor diharapkan }} \times 100 \%$

Untuk keperluan uji kelayakan dari validator, diperlukan pengubahan skor ratarata menjadi nilai kualitatif tersendiri. Tujuannya adalah untuk mengetahui kategori kelayakan dari validator. Menurut Umar (2002), pengubahan skor dapat dilakukan dengan skor tertinggi dikurangi skor terendah dan dibagi dengan jumlah kategori.

$$
R S=\frac{m-n}{B}
$$

Keterangan:

$$
\begin{array}{ll}
\mathrm{RS} & =\text { Rentang skor } \\
\mathrm{m} & =\text { Skor tertinggi } \\
\mathrm{n} & =\text { Skor terendah } \\
\mathrm{b} & =\text { Jumlah kelas }
\end{array}
$$

Berdasarkan rumus diatas maka rentang skor kelayakan adalah sebagai berikut:

$$
R S=\frac{4-1}{4}=0,75
$$

Tabel 5. Kategori Kelayakan Skor

\begin{tabular}{lcl}
\hline No. & Rentang Skor & \multicolumn{1}{c}{ Kategori } \\
\hline 1. & $3,25<\mathrm{X} \leq 4,00$ & Sangat layak \\
2. & $2,5<\mathrm{X} \leq 3,25$ & Layak \\
3. & $1,75<\mathrm{X} \leq 2,5$ & Cukup layak \\
4. & $1<\mathrm{X} \leq 1,75$ & Kurang \\
\hline
\end{tabular}

Dalam kajian ini akan didapatkan empat kategori data yang menunjukkan tingkat kelayakan dari modul yang dibuat. Kelayakan dari sisi materi akan ditentukan berdasarkan ahli materi, kelayakan secara media dinilai berdasarkan ahli media, dan kelayakan secara penggunaan akan dinilai berdasarkan hasil penilaian guru. Selain itu, 
Pembuatan Modul Pembelajaran... (Aldo/ hal. 37-51)

siswa dalam suatu kelas juga turut menilai kelayakan modul dari sisi pengguna.

\section{HASIL DAN PEMBAHASAN}

Kajian ini merupakan jenis penelitian dan pengembangan $(R \& D)$ yang bertujuan mengetahui proses pengembangan dan kelayakan dari modul pembelajaran AutoCAD untuk mata pelajaran APLPIG kelas XI semester ganjil di SMK Negeri 3 Yogyakarta. Kelayakan modul ditinjau berdasarkan ahli materi, ahli media, dan guru mata pelajaran APLPIG di SMK Negeri 3 Yogyakarta. Selain itu, siswa kelas XI kompetensi DPIB juga turut memberikan penilaian sebagai pengguna terhadap produk modul yang telah dikembangkan.

Dari tahapan Front-end analysis (Analisis awal) disusun beberapa permasalahan dan urgensi penyusunan modul pembelajaran yang diantaranya 1) Belum tersedianya modul pembelajaran APLPIG sebagai sumber belajar mandiri bagi siswa kompetensi DPIB kelas XI semester ganjil di SMK Negeri 3 Yogyakarta; 2) Sumber belajar yang saat ini digunakan belum diperbaharui sejak tahun 2004; 3) Beberapa sumber belajar dari internet yang selama ini digunakan belum teruji valid oleh pandangan ahli.

Berdasarkan tahapan Learner analysis (Analisis siswa) dilakukan riset dengan metode observasi dan wawancara kepada guru mata pelajaran APLPIG secara langsung di SMK Negeri 3 Yogyakarta. Wawancara dilakukan tanpa menggunakan pertanyaan yang terstruktur, melainkan dengan pertanyaan yang bebas untuk mengetahui karakteristik siswa dan materi pada mata pelajaran APLPIG di semeseter berikutnya (ganjil).
Dari tahapan Task analysis (Analisis tugas) menjadi proses penyesuaian antara hasil riset mengenai karakteristik siswa terhadap persyaratan kompetensi yang ditetapkan pemerintah pusat. Hasilnya didapatkan garis besar materi modul yang mencakup 1) Definisi perangkat lunak AutoCAD; 2) Keselamatan dan kesehatan kerja dalam mengoperasikan AutoCAD; 3) Tampilan dan tahapan pengelolaan file AutoCAD; 4) Prinsip dasar gambar 2D; 5) Persiapan menggambar dengan AutoCAD; 6) Pembuatan gambar detail; 7) Pembuatan gambar rancangan; 8) Pembuatan etiket dan tahapan pencetakan gambar.

Dari tahapan Concepts analysis (Analisis konsep) disusun beberapa referensi sebagai konsep yang mendukung pembuatan modul dengan delapan isi materi seperti pada penjelasan sebelumnya. Referensi tersebut terdiri dari 1) Buku pembelajaran AutoCAD 2D untuk teknik sipil yang ditulis kolaboratif oleh Nur Hidayat, Dian Eksana Wibowo, dan Ahmad Aldo tahun 2019; 2) Buku bank soal AutoCAD 2D yang ditulis oleh Hari Aria Sona tahun 2005; 3 ) Modul standar penggambaran CAD yang ditulis Aswin Indraprastha tahun 2015; 4) Buku teknik gambar bangunan jilid 1, jilid 2, dan jilid 3 untuk SMK yang ditulis Suparno tahun 2008; dan 5) Buku rancang bangun AutoCAD yang ditulis HR Widada tahun 2011.

Dari tahapan Specifying instructional objectives (Spesifikasi objek instruksional) ditetapkan tujuan pembelajaran dari masingmasing materi yang hendak disusun dalam modul pembelajaran. Tujuan pembelajaran menjadi garis besar isi modul yang hendak dikembangkan. Dengan tujuan pembelajaran yang jelas diharapkan dapat menghasilkan 
modul yang sesuai dengan kebutuhan dan kompetensi dari kurikulum yang diharapkan.

Dari tahapan Consctrucion crietionreferenced test (Penyusunan kriteria) disusun garis besar isi modul. Pada Bab I modul dibahas dua garis besar materi, yaitu tentang definisi perangkat lunak AutoCAD dan Keselamatan dan Kesehatan Kerja (K3) saat penggunaan AutoCAD. Penggabungan dilakukan karena pokok bahasan materi cukup ringkas dan relevan. Kemudian pada Bab II dibahas tampilan dan tahapan pengelolaan file dalam AutoCAD. Materi ini mencakup tentang pembukaan perangkat lunak AutoCAD dan pengenalan perangkat secara umum. Selain itu, Bab ini membahas materi mengenai tahapan pengelolaan file AutoCAD dengan benar. Pada intinya Bab I dan Bab II disusun dengan bahasa sederhana agar tujuan mengenalkan perangkat lunak AutoCAD dan meningkatkan minat belajar siswa tercapai. Untuk materi modul pada Bab III dan Bab IV mulai masuk ke tahapan persiapan sebelum menggambar dengan perangkat AutoCAD. Bab III mencakup bahasan mengenai prinsip dasar gambar dua dimensi, sedangkan Bab IV membahas mengenai persiapan menggambar dengan AutoCAD. Melalui dua Bab ini diharapkan dapat meluruskan prinsip dan persiapan penggambaran yang perlu dikuasai oleh siswa agar pada materi selanjutnya dapat menghasilkan objek gambar yang benar dan sesuai standar. Untuk bagian materi tentang penggambaran dibahas pada Bab V, Bab VI, dan Bab VII. Pada Bab V disampaikan materi tentang pembuatan gambar detail yang terdiri dari gambar detail pondasi, kusen, dan kuda-kuda. Kemudian dalam Bab VI disampaikan materi penggambaran yang lebih luas dengan mencakup penggambaran denah, tampak, dan potongan. Sementara itu, dalam Bab VII disampaikan materi tahapan pembuatan etiket gambar beserta tahapan dalam mencetak gambar.

Dari suatu tahapan Media selection (Pemilihan media) dilakukan penetapan media yang tepat untuk digunakan adalah modul pembelajaran yang disusun secara spesifik dan detail. Modul ini dipilih karena dapat menjadi sumber belajar mandiri bagi siswa.

Dalam tahapan Format selection (Pemilihan format) dilakukan penyusunan format materi dalam modul pembelajaran berdasarkan teori Sungkono (2003) mengenai delapan komponen dalam penyusunan modul berupa: (1) Tinjauan mata pelajaran; (2) Pendahuluan; (3) Kegiatan belajar; (4) Latihan; (5) Ramburambu jawaban latihan; (6) Rangkuman; (7) Tes formatif; dan (8) Kunci jawaban tes formatif. Berdasarkan delapan komponen tersebut dilakukan reduksi menjadi empat komponen yang terdiri dari (1) Tujuan pembelajaran; (2) Uraian materi; (3) Rangkuman; (4) Soal latihan. Bagian tujuan pembelajaran mewakili bagian tinjauan dan pendahuluan isi Bab. Kemudian uraian materi juga membahas bagian pendahuluan dan mencakup tentang pembahasan materi keseluruhan yang disertai dengan contoh kasus pada masing-masing bab. Bagian rangkuman disusun secara ringkas namun mencakup keseluruhan isi masing-masing Bab. Sementara itu, bagian soal latihan mencakup soal teori dan praktik agar menekankan siswa untuk menguasai dimensi kompetensi pengetahuan dan keterampilan. Kunci jawaban tidak tersedia karena jumlah soal didominasi oleh ranah praktik secara langsung dengan perangkat AutoCAD.

Dari suatu tahapan Initial design (Rancangan awal) disusun naskah modul 


\section{Pembuatan Modul Pembelajaran... (Aldo/ hal. 37-51)}

berlandaskan pada tiga tahapan perencanaan sebelumnya. Tahap ini menjadi bagian kajian pengembangan yang paling panjang karena dilakukan selama bulan Februari Juni 2019. Pengembangan modul yang panjang tidak terlepas dari kegiatan konsultasi rutin setiap bulan dengan guru sebagai pengguna modul pembelajaran. Selain itu, pada tahap ini juga dibentuk desain halaman sampul modul sesuai dengan karakteristik siswa SMK.

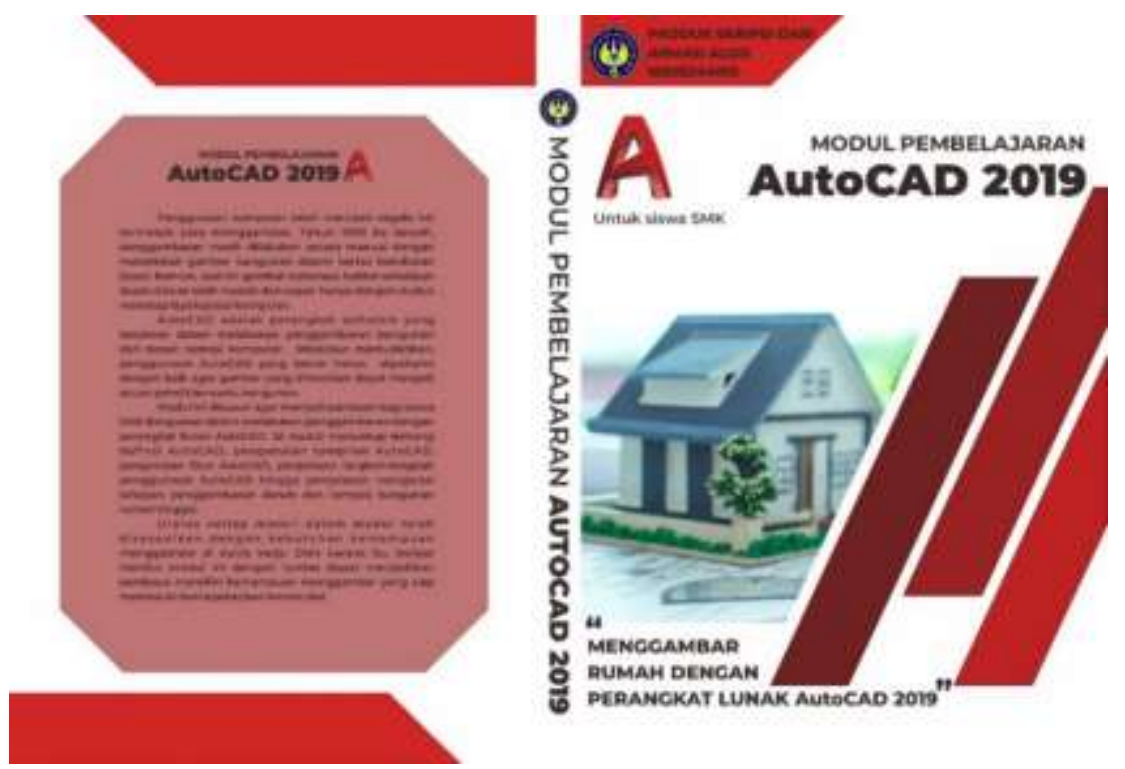

Gambar 2. Sampul Modul AutoCAD 2019

Bagian sampul modul disusun sedemikian rupa agar tidak bertentangan dengan kriteria Badan Standar Nasional Pendidikan (BSNP) mengenai modul teks pelajaran. Adapun kriteria tersebut terdiri dari tata letak sampul modul, tipografi sampul modul, dan ilustrasi sampul modul yang mencerminkan isi. Melalui kriteria tersebut disusun desain sampul modul seperti Gambar 2 di atas.

Sementara itu, untuk isi naskah modul memiliki penjelasan tersendiri. Bab I modul menjelaskan mengenai definisi dan perkembangan AutoCAD yang disertai dengan K3 dalam penggunaan AuoCAD. Melalui Bab ini dikembangkan isi perangkat lunak AutoCAD dan dilengkapi dengan sejarah singkat perkembangan perangkat AutoCAD. Dalam Bab II disampaikan pembahasan materi yang lebih lanjut mengenai tampilan dan tahapan dalam pengelolaan file AutoCAD. Pembahasan bab ini mencakup pembukaan, penutupan, penyimpanan, dan penyelamatan file AutoCAD yang telah dibuat. Dalam Bab III disampaikan materi mengenai prinsip dasar gambar dua dimensi. Bab ini membahas teori yang perlu dikuasai dan diterapkan dalam penggambaran AutoCAD karena memberikan manfaat besar bagi pengguna. Selanjutnya dalam isi Bab IV disampaikan pembahasan mengenai berbagai persiapan yang perlu dilakukan sebelum menggambar dengan AutoCAD. Dari bab ini diharapkan dapat menjadikan peserta didik mampu menerapkannya pada setiap penggambaran karena membuat suatu proses penggambaran dapat berjalan lebih mudah (efektif) dan cepat (efisien).

Untuk pembahasan materi tentang proses penggambaran terdapat pada $\mathrm{Bab} \mathrm{V}$, Bab VI, dan Bab VII yang saling terhubung. 
Pada Bab V dibahas mengenai tahapan pembuatan gambar detail pondasi, pintu, dan kuda-kuda untuk bagian atap bangunan. Tiga detail tersebut dibahas secara khusus dalam suatu bab karena penguasaan materinya diperlukan dalam memasuki dunia kerja, khususnya yang terlibat dalam perusahaan pembangunan gedung maupun perumahan. Sementara itu, materi Bab VI mencakup pembahasan mengenai tahapan pembuatan gambar rancangan yang terdiri dari denah, tampak, dan potongan. Tiga gambar tersebut menggunakan objek detail yang sama dengan yang dibahas pada materi Bab V. Sementara itu, Bab VII menjadi Bab yang mengintegrasikan Bab V dan Bab VI. Hal ini disebabkan karena pada Bab tersebut dibahas mengenai tahapan pembuatan etiket dan pencetakan gambar detail dan gambar rancangan yang telah terbuat pada layar AutoCAD ke dalam kertas A4.

Dalam tahapan penelitian Expert apprasial dilaksanakan kegiatan validasi pada tanggal 2 Oktober 2019 atau bertepatan dengan jadwal mata pelajaran APLPIG untuk kelas XI DPIB 3. Ahli materi dan ahli media diberikan waktu dua hari untuk membaca dan melakukan validasi modul pembelajaran. Sementara guru langsung melakukan validasi modul pembelajaran di hari yang sama. Setiap kesalahan dan kekurangan dalam penulisan modul disampaikan secara tertulis dalam kolom komentar dari lembar validasi modul masing-masing.

Setelah melalui proses validasi, maka disusun seluruh hasil komentar yang telah diberikan oleh ahli materi, ahli media, dan guru. Namun demikian, revisi hanya dilakukan apabila isi modul memang tidak sesuai dengan teori yang disampaikan pada bagian kajian pustaka. Masing-masing saran untuk perbaikan dari ahli materi, ahli media, dan guru disusun seperti pada Tabel 6 .

Tabel 6. Daftar Saran Perbaikan dari Ahli Materi, Ahli Media, dan Guru

\begin{tabular}{|c|c|c|c|}
\hline No & Saran Revisi & Sebelum Revisi & Sesudah Revisi \\
\hline 1. & $\begin{array}{l}\text { Fungsi fitur Grid, Ortho } \\
\text { dan Snap lebih dijelaskan } \\
\text { lagi (Halaman 28) }\end{array}$ & $\begin{array}{l}\text { Fitur Grid, Ortho dan Snap } \\
\text { hanya mencakup tombol } \\
\text { khusus }\end{array}$ & $\begin{array}{l}\text { Masing-masing fitur Grid, Ortho dan } \\
\text { Snap ditambahkan penjelasan }\end{array}$ \\
\hline 2. & $\begin{array}{l}\text { Pengenalan tool dasar perlu } \\
\text { ditampilkan dalam modul } \\
\text { (Halaman 44) }\end{array}$ & $\begin{array}{l}\text { Isi modul belum dilengkapi } \\
\text { dengan penjelasan } \\
\text { mengenai beberapa tool } \\
\text { dasar }\end{array}$ & $\begin{array}{l}\text { Pengenalan tool ditampilkan pada akhir } \\
\text { Bab IV tentang Persiapan Menggambar } \\
\text { dengan AutoCAD }\end{array}$ \\
\hline 3. & $\begin{array}{l}\text { Gambar detail pondasi } \\
\text { belum dilengkapi arsir } \\
\text { adukan trassram } 1: 3 \\
\text { (Halaman } 47 \text { ) }\end{array}$ & $\begin{array}{l}\text { Gambar detail pondasi } \\
\text { menggunakan arsir adukan } \\
\text { spesi 1:4 dan bukan arsir } \\
\text { adukan trassram } 1: 3\end{array}$ & $\begin{array}{l}\text { Gambar detail pondasi keseluruhan } \\
\text { dalam isi modul direvisi dengan } \\
\text { menggunakan adukan trassram } 1: 3\end{array}$ \\
\hline 4. & $\begin{array}{l}\text { Penulisan naskah harus } \\
\text { menggunakan kata modul } \\
\text { dan bukan buku (halaman } \\
\text { 48) }\end{array}$ & $\begin{array}{l}\text { Penulisan naskah masih } \\
\text { menggunakan kata buku }\end{array}$ & $\begin{array}{l}\text { Isi modul yang menggunakan kata buku } \\
\text { diganti menjadi modul }\end{array}$ \\
\hline
\end{tabular}


Pembuatan Modul Pembelajaran... (Aldo/ hal. 37-51)

\begin{tabular}{|c|c|c|c|}
\hline No & Saran Revisi & Sebelum Revisi & Sesudah Revisi \\
\hline 5. & $\begin{array}{l}\text { Langkah pembuatan detail } \\
\text { pondasi nomor } 5 \text { dan } 6 \\
\text { diperjelas (halaman 50) }\end{array}$ & $\begin{array}{l}\text { Penjelasan pembuatan detail } \\
\text { pondasi masih kurang } \\
\text { lengkap }\end{array}$ & $\begin{array}{l}\text { Langkah pembuatan detail pondasi } \\
\text { diperjelas dalam bentuk narasi }\end{array}$ \\
\hline 6. & $\begin{array}{l}\text { Langkah pembuatan kusen } \\
\text { dilengkapi dengan } \\
\text { penjelasan pemberian arsir } \\
\text { (halaman 63) }\end{array}$ & $\begin{array}{l}\text { Arsir langsung diberikan } \\
\text { tanpa penjelasan langkah } \\
\text { pemberiannya }\end{array}$ & $\begin{array}{l}\text { Penjelasan pemberian arsir disampaikan } \\
\text { dalam bentuk narasi }\end{array}$ \\
\hline 7. & $\begin{array}{l}\text { Langkah penjelasan } \\
\text { penggambaran reng perlu } \\
\text { diperbaiki (halaman 66) }\end{array}$ & $\begin{array}{l}\text { Penjelasan penggambaran } \\
\text { reng masih salah dan belum } \\
\text { menggunakan tata bahasa } \\
\text { yang sederhana }\end{array}$ & $\begin{array}{l}\text { Isi penjelasan penggambaran reng } \\
\text { diperbaiki dan disusun dengan tata } \\
\text { bahasa yang lebih sederhana }\end{array}$ \\
\hline 8. & $\begin{array}{l}\text { Langkah penggambaran } \\
\text { detail A masih belum tepat } \\
\text { (halaman } 71 \text { ) }\end{array}$ & $\begin{array}{l}\text { Gambar plat baja pada } \\
\text { detail kuda-kuda A belum } \\
\text { tepat }\end{array}$ & $\begin{array}{l}\text { Dilakukan perbaikan gambar plat baja } \\
\text { pada seluruh langkah penggambaran } \\
\text { kuda-kuda A }\end{array}$ \\
\hline 9. & $\begin{array}{l}\text { Gambar konstruksi perlu } \\
\text { diperbaiki sesuai standar } \\
\text { yang telah ditetapkan }\end{array}$ & $\begin{array}{l}\text { Beberapa gambar } \\
\text { konstruksi masih belum } \\
\text { berdasarkan standar yang } \\
\text { tepat }\end{array}$ & $\begin{array}{l}\text { Disusun gambar konstruksi yang } \\
\text { berdasarkan pada teori Pedoman Teknis } \\
\text { Bangunan Tahan Gempa dari } \\
\text { Departemen Pekerjaan Umum (2006) } \\
\text { dan Standar Bangunan Rumah Rakyat } \\
\text { Tahan Gempa (2006) }\end{array}$ \\
\hline 10. & $\begin{array}{l}\text { Penggunaan simbol-simbol } \\
\text { gambar perlu disesuaikan } \\
\text { dengan standar }\end{array}$ & $\begin{array}{l}\text { Beberapa simbol gambar } \\
\text { belum berdasarkan standar } \\
\text { yang tepat }\end{array}$ & $\begin{array}{l}\text { Disusun ulang gambar konstruksi yang } \\
\text { belum terstandar dengan mengacu } \\
\text { simbol dari dua standar pada daftar } \\
\text { saran nomor } 8\end{array}$ \\
\hline
\end{tabular}

Dari tahapan Developmental testing dijelaskan hasil penilaian produk modul pembelajaran yang dilakukan siswa di dalam suatu kelas. Siswa yang menjadi responden dalam kajian adalah kelas XI DPIB 3 dari SMK Negeri 3 Yogyakarta. Adapun total responden yang menjadi subjek tahap developmental testing adalah sebanyak 30 siswa. Tahap pengembangan ini menjadi proses penilaian bagi siswa dengan membaca modul secara langsung. Penilaian ini menjadi tahap terakhir untuk mengetahui kekurangan dan hasil penilaian modul. Kekurangan modul akan direvisi setelah tahap ini dan hasil penilaian modul ditentukan dengan menggunakan tabel kecenderungan. Penilaian dilakukan pada tanggal 23 Oktober 2019 di Ruang Lab
AutoCAD nomor 14. Penilaian dilaksanakan pada pukul 15.00-16.30 WIB. Penilaian dilakukan oleh siswa dari mata pelajaran APLPIG kelas XI DPIB 3 dengan jumlah responden 30 orang dari 32 siswa.

Adapun kegiatan penilaian dilakukan dengan langkah berikut: (1) Membuka sesi penilaian poduk; (2) Menyampaikan maksud dan tujuan; (3) Membagikan modul dalam bentuk soft file ke siswa; (4) Membagikan hard file angket instrumen kajian; (5) Menyampaikan tahapan pengisian modul; (6) Meminta setiap siswa untuk menilai dan mengomentari modul secara jujur; (7) Mengumpulkan hasil penilaian modul; dan (8) Menutup sesi penilaian modul di dalam kelas. 
Pembuatan Modul Pembelajaran... (Aldo/ hal. 37-51)

Berdasarkan hasil penilaian produk didapatkan beberapa komentar untuk perbaikan modul. Namun demikian, semua komentar siswa hanya mengarah ke sampul dan penulisan dari modul. Hal ini dapat diterima karena peserta didik baru mempelajari mata pelajaran APLPIG dalam satu semeseter sehingga belum cukup mampu mengkritisi isi materi modul. Adapun beberapa komentar yang diterima ditampilkan pada Tabel 7.

Tabel 7. Daftar Saran Perbaikan dari Hasil Penilaian Siswa

\begin{tabular}{clll}
\hline No & \multicolumn{1}{c}{ Saran Revisi } & \multicolumn{1}{c}{ Sebelum Revisi } & \multicolumn{1}{c}{ Sesudah Revisi } \\
\hline 1. & $\begin{array}{l}\text { Kesalahan penulisan perlu } \\
\text { diperbaiki sebelum } \\
\text { dipublikasikan }\end{array}$ & $\begin{array}{l}\text { Beberapa bagian modul masih } \\
\text { memiliki kesalahan pada } \\
\text { penulisan kata dan kalimat }\end{array}$ & $\begin{array}{l}\text { Keseluruhan isi modul dilakukan } \\
\text { perbaikan kata dan kalimat }\end{array}$ \\
2. $\begin{array}{l}\text { Penjelasan pada bagian } \\
\text { pembuatan gambar perlu } \\
\text { disederhanakan kembali }\end{array}$ & $\begin{array}{l}\text { Langkah proses penggambaran } \\
\text { masih cenderung sulit dipahami }\end{array}$ & $\begin{array}{l}\text { Dilakukan penyederhanan kembali } \\
\text { pada langkah penggambaran yang } \\
\text { sulit dipahami seperti gambar detail }\end{array}$ \\
& $\begin{array}{l}\text { Penggunaan huruf dan } \\
\text { perletakannya pada sampul } \\
\text { sebaiknya diperbaiki agar } \\
\text { tidak berlebihan }\end{array}$ & $\begin{array}{l}\text { Bagian sampul masih } \\
\text { menggunakan huruf yang } \\
\text { memiliki ketebalan sangat } \\
\text { kontras dan perletakan yang } \\
\text { belum tepat }\end{array}$ & $\begin{array}{l}\text { Sampul modul sedikit diperbaiki } \\
\text { agar tidak berlebihan }\end{array}$ \\
& & \\
\hline
\end{tabular}

Tahap penyebaran seharusnya terdiri dari a) Validation testing; b) Packaging; c) Diffusion and adaption. Namun tahap Validation testing belum dapat dilaksanakan karena produk modul baru selesai divalidasi setelah mendekati akhir semester ganjil dan siswa telah menguasai sebagian besar materi dalam modul. Oleh karenanya, tahap Validation testing dapat dilakukan pada tahun ajaran berikutnya oleh guru. Selain itu, untuk tahap packaging, diffusion and adoption dilaksanakan dengan memberikan modul pembelajaran dalam bentuk soft file dan hard file pada guru mata pelajaran APLPIG di SMK Negeri 3 Yogyakarta.

Kajian ini pada dasarnya merupakan jenis penelitian pengembangan yang mengembangkan modul sebagai media pembelajaran AutoCAD untuk mata pelajaran APLPIG kelas XI semester ganjil. Adapun pengembangan modul dibatasi untuk lingkup pembelajaran di SMK Negeri 3 Yogyakarta.

Penyusunan modul pembelajaran didasari atas permasalahan belum tersedianya media pembelajaran modul yang memadai sebagai sumber belajar mandiri yang sesuai tuntutan Kurikulum 2013 Revisi. Akibatnya proses pembelajaran masih bergantung pada penjelasan guru. Selain itu, sumber belajar mata pelajaran APLPIG yang digunakan di SMK Negeri 3 Yogyakarta saat ini telah diterapkan sejak tahun 2004 dan perlu diperbaharui sesuai perkembangan zaman.

Model pengembangan yang digunakan adalah model 4-D dari Thiagarajan yang meliputi tahap pendefinisian, perancangan, pengembangan, dan penyebarluasan. Adapun produk modul pembelajaran divalidasi oleh ahli yang terdiri dari ahli materi, ahli media, dan guru. 
Pembuatan Modul Pembelajaran... (Aldo/ hal. 37-51)

Selain itu, dalam tahap pengembangan juga memberikan kesempatan bagi siswa untuk menilai modul dari sisi pengguna.

Berdasarkan hasil validasi oleh ahli materi mendapatkan skor 3,55 yang berada pada interval skor $3,25<\mathrm{X} \leq 4,00$ sehingga masuk dalam kategori sangat layak. Sedangkan hasil validasi ahli media medapatkan skor 3 yang berada pada interval skor 2,5 $<\mathrm{X} \leq 3,25$ sehingga masuk kategori layak. Sementara itu, hasil validasi guru mendapatkan skor 2,95 yang juga berada pada interval skor $2,5<\mathrm{X} \leq 3,25$ sehingga masuk kategori layak. Adapun uraian masing-masing tersebut dapat dilihat pada Tabel 8, 9, dan 10 di bawah.

Tabel 8. Skor Kelayakan Modul Menurut Ahli Media

\begin{tabular}{clc}
\multicolumn{3}{c}{ Media } \\
\hline No. & Komponen Penilaian & Jumlah Skor \\
\hline 1. & Ukuran Modul & 6 \\
2. & Desain Sampul Modul & 52 \\
3. & Desain Isi Modul & 101 \\
& Total skor & 159 \\
& Skor maksimum & 212 \\
& Skor dalam skala 4 & 3 \\
\hline
\end{tabular}

Tabel 9. Skor Kelayakan Modul Menurut Ahli Materi

\begin{tabular}{clc}
\multicolumn{3}{c}{ Materi } \\
\hline No. & \multicolumn{1}{c}{ Komponen Penilaian } & Jumlah Skor \\
\hline 1. & Self Instruction & 25 \\
2. & Self Contained & 13 \\
3. & Stand Alone & 8 \\
4. & Adaptive & 6 \\
5. & User Friendly & 12 \\
& & 64 \\
& Skor maksimum & 72 \\
& Total skor dalam skala 4 & 3,55 \\
\hline
\end{tabular}

Tabel 10. Skor Kelayakan Modul Menurut Guru

\begin{tabular}{clc}
\hline No. & Komponen Penilaian & Jumlah Skor \\
\hline 1. & Self Instruction & 19 \\
2. & Self Contained & 11 \\
3. & Stand Alone & 4 \\
4. & Adaptive & 6 \\
5. & User Friendly & 9 \\
6. & Ukuran Modul & 8 \\
7. & Desain Sampul Modul & 54
\end{tabular}

\begin{tabular}{ccc}
\hline No. & Komponen Penilaian & Jumlah Skor \\
\hline 8. & Desain Isi Modul & 99 \\
& Total skor & 210 \\
& Skor maksimum & 284 \\
& Skor dalam skala 4 & 2,95 \\
\hline
\end{tabular}

Di sisi lain, berdasarkan hasil penilaian 30 siswa sebagai responden menunjukkan bahwa masing-masing komponen penilaian menunjukkan kecenderungan sebagai berikut: 1) Komponen Self Instruction cenderung masuk kategori layak dengan dipilih tujuh belas responden $(57 \%)$; 2) Komponen Self Contained cenderung masuk kategori layak dengan dipilih empat belas responden (47\%); 3) Komponen Stand Alone cenderung masuk kategori cukup layak dengan dipilih dua puluh responden $(67 \%)$; 4) Komponen Adaptive cenderung masuk kategori sangat layak dengan dipilih empat belas responden (47\%); 5) Komponen User Friendly cenderung masuk kategori sangat layak dengan dipilih 21 responden (70\%); 6) Komponen ukuran modul cenderung masuk kategori sangat layak dengan dipilih tujuh belas responden (57\%); 7) Komponen desain sampul modul cenderung masuk kategori sangat layak dengan dipilih 21 responden (70\%); 8) Komponen desain isi modul cenderung masuk kategori sangat layak dengan dipilih 23 responden (77\%).

Selama pelaksanaan kajian terdapat beberapa keterbatasan kajian. Keterbatasan ini terjadi disebabkan oleh faktor subjek pengambilan data, waktu, dan efisiensi kajian. Berikut ini disampaikan beberapa keterbatasan dalam kajian pembuatan modul AutoCAD: 1) Proses penilaian modul pada siswa dengan tiga puluh responden dilaksanakan dengan menggunakan modul $e$-book. Sebenarnya untuk pengambilan data yang valid harus memberikan responden 
suatu modul print out utuh. Namun demikian, penilaian modul yang berbentuk $e$-book dipilih agar meningkatkan efisiensi waktu dan biaya kajian. Selain itu, 2) Pengujian modul dilaksanakan dengan memberikan siswa batasan waktu membaca modul selama tiga pulih menit dan langsung memberikan penilaian. Hal ini merupakan suatu keterbatasan karena sebaiknya penilaian diteruskan dengan menerapkan modul sebagai media pembelajaran sesungguhnya dan kemudian melakukan penilaian isi modul.

\section{SIMPULAN}

Berdasarkan hasil kajian tentang pembuatan modul pembelajaran AutoCAD untuk mata pelajaran Aplikasi Perangkat Lunak dan Perancangan Interior Gedung (APLPIG) di SMK Negeri 3 Yogyakarta, dapat ditarik dua kesimpulan sebagai berikut: 1) Produk dapat dikembangkan dengan empat tahapan kajian yang menghasilkan produk dengan materi mencakup a) Definisi perangkat lunak AutoCAD; b) Tampilan dan tahapan pengelolaan file AutoCAD; c) Prinsip gambar dua dimensi; d) Periapan menggambar dengan AutoCAD; e) Pembuatan gambar detail; f) Pembuatan gambar rancangan; g) Pembuatan etiket gambar dan pencetakan gambar.

Sementara itu, 2) Tingkat kelayakan maupun penilaian modul berdasarkan ahli materi, ahli media, guru, dan siswa menunjukkan hasil yang berbeda-beda. Hasil validasi oleh ahli materi mendapatkan skor 3,55 dengan kategori sangat layak, sedangkan berdasarkan validasi ahli media mendapatkan skor 3 dengan kategori layak. Sementara itu, hasil validasi guru sebagai pendidik mendapatkan skor 2,95 dengan kategori layak.

\section{DAFTAR RUJUKAN}

Andi, P. (2012). Panduan kreatif membuat bahan ajar inovatif. Yogyakarta: Diva Press.

Anwar, M.I. (2007). Skala pengukuran variabel-variabel penelitian. Bandung: Alfabeta.

Arikunto, S. (2006). Prosedur penelitian. Jakarta: Rineka Cikta.

Borg, W.R. \& Gall, M.D. (1983). Educational research: and introduction (seventh edition). New York and London: Longman Inc.

BPS. (2019). Lulusan SMK Mendominasi Tingkat Pengangguran Terbuka. Diambil pada tanggal 24 September 2019 dari databoks.katadata.co.id/datapublish /2019/05/07/lulusan-smkmendominasi-tingkat-pengangguranterbuka.

BSNP. (2014). Publikasi Badan Standar Nasional Pendidikan tentang instrumen modul teks pelajaran. Jakarta.

Depdiknas. (2003). Undang-Undang Republik Indonesia No. 20 tahun 2003 tentang Sistem Pendidikan Nasional. Jakarta.

Depdiknas. (2008). Penulisan modul. Jakarta: Direktorat Tenaga Kependidikan.

Pratama, G. N. I. P. (2019, May). Basic communication skill drill in microteching context to improve the teching skills of civil engineering and planning education students, faculty of engineering, Yogyakarta State 
Pembuatan Modul Pembelajaran... (Aldo/ hal. 37-51)

University. In IOP Conference Series: Materials Science and Engineering (Vol. 535, No. 1, p. 012014). IOP Publishing.

Pratama, G. N. I. P., \& Suparman, S. (2019). PENINGKATAN KETERAMPILAN MENGAJAR MAHASISWA PENDIDIKAN TEKNIK SIPIL DAN PERENCANAAN, FT, UNY MELALUI METODE DRILL BERBASIS KOMUNIKASI VERBAL-NON VERBAL. Jurnal Pendidikan Teknik Sipil, 1(1).

Sukiman. (2011). Pengembangan media pembelajaran. Yogyakarta: Pustaka Insan Madani.

Sungkono, D.S., Wirasti, S., Suyanto, S. et al. (2009). Pengembangan bahan ajar. Yogyakarta: FIP UNY.

Thiagarajan, S., Semmel, D.S., Semmel, M.I. (1974). Development for Training Teacher of Exeptional Children: A
Sourcebook. Indiana: Indiana University.

Triyono, B. M., Mohib, N., Kassymova, G. K., Pratama, G. N., Adinda, D., \& Arpentieva, M. R. (2020). The Profile Improvement of Vocational School Teachers' Competencies. Vysshee obrazovanie $v$ Rossii $=$ Higher Education in Russia, 29(2), 151-158.

Umar, Husein (2002). Metode penelitian dalam aplikasi pemasaran. Jakarta: PT Gramedia Pustaka Utama.

Wulandari, B., Pratama, G. N. I. P., Hasanah, N., \& Yuniarti, N. (2019, November). Augmented Reality As Android Based Learning Media for Wood Field Laboratory Work. In Journal of Physics: Conference Series (Vol. 1413, No. 1, p. 012035). IOP Publishing. 